\title{
Participation of Farmers in Agricultural Extension Activities of Raitha Samparka Kendras
}

\author{
M. E. Darshan*, M. T. Lakshminarayan and K. G. Banuprakash \\ Department of Agricultural Extension, India \\ University of Agricultural Sciences, Bengaluru, India \\ *Corresponding author
}

Keywords Participation, Extension activities, Raitha Samparka Kendras, Profile characteristics

Article Info

Accepted:

10 August 2019 Available Online: 10 September 2019

\section{A B S T R A C T}

The present study was conducted in 12 Raitha Samparka Kendras (RSKs) of Tumukuru district of Karnataka state during 2017-2018 to know the extent of participation of farmers in agricultural extension activities of RSKs. One hundred twenty farmers who availed agricultural extension services of RSKs were interviewed using a pre-tested interview schedule. The results revealed that a vast majority of farmers had 'contacted' the agricultural extension functionaries in RSKs through mobile (85.00\%) and landline phone $(81.66 \%)$. A majority of farmers had 'participated' in the agricultural extension activities such as meetings/discussion (73.33\%), training programmes (68.33\%), field visits (59.16\%), method demonstration $(52.50 \%)$ and result demonstration $(50.83 \%)$ organized by RSKs. Majority of the farmers (68.34\%) were having to medium to high level of participation in the agricultural extension activities of RSKs. Education, achievement motivation, management orientation, scientific orientation, mass media participation and extension agency contact of farmers had significant to highly significant relationship with their participation in agricultural extension activities.

\section{Introduction}

Considering the importance of the need to provide effective extension services to the farmers, Raitha Mitra Yojane, a demand driven Agricultural Extension System was initiated in Karnataka state during 2001, replacing the earlier extension system (Training and Visit system) by establishing agricultural extension centres at hobli levels called as Raitha Samparka Kendras (Agricultural Extension Centres). Till now, 747 Raitha Samparka Kendras (RSKs) are established in Karnataka state at Hobli/ Subblock level in 176 taluks). These RSKs located in proximity to the farming community are aimed at addressing wide range of issues related to agriculture. They 
also act as common platform by creating a terminal linkage to the farmers to access and interact about agriculture based technology and information at the grass root level (Raghuprasad et al., 2012).

The main objectives of Raitha Samparka Kendras are : (1) to provide updated information on crop selection, crop production related know-how and market information, (2) to facilitate on site provision of critical inputs like seeds, bio-fertilizers, micro-nutrients etc. (3) to provide primary seed and soil testing facilities, and (4) to provide a forum for onfarm demonstration about new technologies developed by both public and private sector agencies.

The main functions of the Raitha Samparka Kendras (RSKs) includes : (1) to transfer the recommended technologies to the farmers, (2) giving wide publicity to the local institutions through individual, group and mass extension methods regarding input availability and its subsidy, (3) organizing extension activities like meetings/discussion, training programmes, demonstrations, farmers field school, video conferring, field days etc., and (4) distribution of agricultural inputs (Raghupathi et al., 2011). With this background, the present study was undertaken with the following specific objectives;

To know the personal, socio-economic, psychological and communication characterizes of farmers.

To study the extent of participation of farmers in agricultural extension activities conducted under Raitha samparka kendras.

To find out the association and extent of contribution of the personal, socio-economic, psychological and communication characteristics of farmers on their participation in agricultural extension activities

\section{Materials and Methods}

The present study was conducted during 20172018 in Tumakuru district of Karnataka State. Tumakuru district comprises of ten taluks, having 50 Hoblis (sub- blocks) and 50 RSKs. Four taluks namely, Gubbi (6 Nos.), Kunigal (6 Nos.), Madhugiri (6 Nos.) and Tumakuru (6 Nos.) were purposively selected for the study, since these four taluks were having maximum number of Raitha Samparka Kendras among the ten taluks of Tumakuru district. Three RSKs were randomly selected for the study from each of the four sampled taluks, thus 12 RSKs were selected from selected for the study from Gubbi, Kunigal, Madhugiri and Tumakuru taluks from Tumakuru district. One hundred and twenty farmers who availed the agricultural extension services in Raitha Samparka Kendras were randomly selected from 12 RSKs for the study. Ex-post-facto research design was adopted in the present study. Data was collected using a pre-tested interview schedule. The collected data analyzed using, mean, standard deviation, zero order correlation test and multiple regression analysis.

Extent of participation of farmers in the agricultural extension activities of Raitha Samparka Kendras (Dependent variable)

The extent of participation of farmers in the present study refers to the participation of respondents in the various agricultural extension activities organised and conducted by Raitha Samparka Kendras during the last six months (September 2017 to February 2018). Meetings/discussion, method demonstration, result demonstration, fields visits, training programmes, farmers field school, video conference, field day/ kshrothsava, agricultural campaign, agricultural exhibition, radio, television and internet were the agricultural extension activities conducted by Raitha Samparka 
Kendras during September 2017 to February 2018. Besides, mobile and land line phone calls were also used by Agricultural extension functionaries at RSKs to disseminate information on agricultural technologies, agricultural programmes etc. to the farmers. The respondents were asked to indicate whether they had participated or not participated in the agricultural extension activities of RSKs. Score of 0 and 1 was assigned for the 'non participation' and 'participation' of respondents in the agricultural extension activities of RSKs, respectively. The minimum and maximum score one could get was 0 and 15, respectively. Based on the total score obtained, the respondents were categorised into low, medium and high level of participation in agricultural extension activities considering mean (8.30) and half standard deviation (1.38) as a measure of check.

\begin{tabular}{|l|c|c|}
\hline Category & Criteria & Score \\
\hline Low & $<($ Mean $-1 / 2 \mathrm{SD})$ & $<6.92$ \\
\hline Medium & $($ Mean $\pm 1 / 2 \mathrm{SD})$ & $6.92-9.68$ \\
\hline High & $>($ Mean $+1 / 2 \mathrm{SD})$ & $>9.68$ \\
\hline
\end{tabular}

Information regarding ten personal, socioeconomic, psychological and communication characteristics of farmers (independent variables) were measured using suitable procedures/scales. The collected data was scored, tabulated and analyzed using frequency, percentage, mean, standard deviation, zero order correlation test and multiple regression analysis.

\section{Results and Discussion}

Personal, socio-economic, psychological and communication characteristics of beneficiary farmers

Table 1 presents the findings on the personal, socio-economic, psychological and communication characteristics of farmers.
It is observed from Table 1 that half of the farmers $(50.00 \%)$ were of middle age, while 29.17 and 20.83 per cent of the farmers were of young age and old age, respectively. Onethird $(33.33 \%)$ of the farmers had studied up to high school followed by $22.50,19.17,11.67$ and five per cent of the farmers had studied up to pre-university, graduation and above, middle school and primary school, respectively. The remaining 8.33 per cent of the farmers were illiterates. Majority of the respondents $(55.80 \%)$ were small farmers, while one -fourth of the respondents were marginal farmers $(25.00 \%)$ and the remaining 19.20 per cent of the respondents were big farmers.

A good number of the farmers $(45.00 \%)$ were belonging to low category of annual income and 37.50 per cent of the farmers were belonging to medium category of annual income. A little less than one-fifth of the farmers $(17.50 \%)$ were belonging to high category of annual income (Table 1).

Fifty per cent of the farmers had moderate farming experience, whereas 29.17 and 20.83 per cent of the farmers had less and more farming experience, respectively. A larger number of farmers $(39.17 \%)$ were having medium level of achievement motivation, while 36.66 per cent had high level of achievement motivation and the remaining 24.17 per cent of the farmers were having low level of achievement motivation.

As high as 40.83 per cent of the farmers had high level of management orientation. while 35.00 per cent of the respondents were having low level of management orientation and the remaining 24.17 per cent of the farmers were having low level of management orientation (Table 1). More number of farmers $(46.67 \%)$ were belonging to high level of scientific orientation. On the other hand one-third of the farmers $(33.33 \%)$ and 20.00 per cent of the farmers were belonging to medium and low level of scientific orientation, respectively. 
Forty per cent of the farmers were belonging to high category of mass media participation, while 32.50 and 27.50 per cent of the farmers were belonging to medium and low category of mass media participation, respectively. As high as 43.34 per cent of the farmers had high level of extension agency contact, whereas 30.83 and 25.83 per cent of the farmers had medium and low level of extension agency contact, respectively.

Table 1 shows that a greater proportion of farmers were of middle age $(50.00 \%)$, small farmers $(55.80 \%)$ studied up to high school $(33.33 \%)$ and were belonging to low level of annual income category (45.00\%). Half of the respondents $(50.00 \%)$ had moderate experience in farming, while more number of respondents were having medium level of achievement motivation (39.17\%).

A larger number of respondents had high level of management orientation $(40.83 \%)$, scientific orientation $(46.47 \%)$, mass media participation $(40.00 \%)$ and extension agency contact (43.34\%). More or less similar findings were observed by Ramappa Patil (2014) and Sunil Vasant More (2014).

\section{Participation of farmers in the agricultural extension activities of Raitha Samparka Kendras}

It is observed from Table 2 that a vast majority of farmers had 'contacted' the agricultural extension functionaries in RSKs through mobile $(85.00 \%)$ and landline phone $(81.66 \%)$.

A majority of farmers had 'participated' in the agricultural extension activities such as meetings/discussion (73.33\%), training programmes $(68.33 \%)$, field visits $(59.16 \%)$, method demonstration $(52.50 \%)$ and result demonstration $(50.83 \%)$ organized by RSKs.
While, a majority of farmers had "not participated' in the extension activities such as, video conference $(86.67 \%)$, farmers field school (75.00\%), agricultural exhibition (65.84\%), agricultural campaign (57.50\%), field days/ kshethrotsava (54.17\%) organized by RSKs.

A vast majority of farmers have not referred radio $(81.67 \%)$, television $(83.34 \%)$ and internet $(90.83 \%)$ for getting information on farm technology, agricultural programmes etc.

The results in Table 2 reveals that a majority of farmers have participated in a variety of agricultural extension activities viz., meetings/discussion, training programmes, field visits, method demonstration and result demonstration conducted by RSKs.

Mobile and landline phones were also used by majority of farmers to contact extension functionaries for obtaining information on agricultural programmes, improved farming technologies, availability of agricultural inputs etc.

It is also observed from Table 2 that a larger number of farmers have not participated in video conference, farmers field schools, agricultural exhibitions, agricultural campaign and field day/kshethrotsava organized by RSKs. Radio, television and internet were not also referred by vast majority of farmers to get information on farm technology, agricultural programmes etc.

The farmers during the interview mentioned that due to lack of time and lack of knowledge on the venue and conduct of extension activities, they could not able to participate/refer the above mentioned extension activities conducted by RSKs. More or less similar findings were reported by Avinash (2013). 
Table.1 Personal, socio-economic, psychological and communication characteristics of farmers

\begin{tabular}{|c|c|c|c|c|}
\hline \multirow{2}{*}{$\begin{array}{l}\text { Sl. } \\
\text { No. }\end{array}$} & \multirow[t]{2}{*}{ Characteristics } & \multirow[t]{2}{*}{ Category } & \multicolumn{2}{|c|}{ Farmers } \\
\hline & & & No. & $\%$ \\
\hline \multirow[t]{3}{*}{1.} & \multirow[t]{3}{*}{ Age } & Young (<35 years) & 35 & 29.17 \\
\hline & & Middle (35 to 50 years) & 60 & 50.00 \\
\hline & & Old $(>50$ years $)$ & 25 & 20.83 \\
\hline \multirow[t]{6}{*}{2.} & \multirow[t]{6}{*}{ Education } & Illiterate & 10 & 08.33 \\
\hline & & Primary school & 6 & 05.00 \\
\hline & & Middle school & 14 & 11.67 \\
\hline & & High school & 40 & 33.33 \\
\hline & & Pre university & 27 & 22.50 \\
\hline & & Graduation and above & 23 & 19.17 \\
\hline \multirow[t]{3}{*}{3.} & \multirow[t]{3}{*}{ Land holding } & Marginal farmers & 30 & 25.00 \\
\hline & & Small farmers & 67 & 55.80 \\
\hline & & Big farmers & 23 & 19.20 \\
\hline \multirow[t]{3}{*}{4.} & \multirow[t]{3}{*}{ Annual income } & Low $(<\operatorname{Rs} 50000)$ & 54 & 45.00 \\
\hline & & Medium(50000-1 lakh) & 45 & 37.50 \\
\hline & & $\operatorname{High}(>\operatorname{Rs} 1$ lakh $)$ & 21 & 17.50 \\
\hline \multirow[t]{3}{*}{5.} & \multirow[t]{3}{*}{ Farming experience } & Less $(<8$ years $)$ & 35 & 29.17 \\
\hline & & Moderate ( $8-16$ years) & 60 & 50.00 \\
\hline & & More (>16 years) & 25 & 20.83 \\
\hline \multirow[t]{3}{*}{6.} & \multirow{3}{*}{$\begin{array}{l}\text { Achievement } \\
\text { motivation }\end{array}$} & Low (<22.73 score $)$ & 29 & 24.17 \\
\hline & & Medium (22.73-24.49 & 47 & 39.17 \\
\hline & & High (>24.49 score) & 44 & 36.66 \\
\hline \multirow[t]{3}{*}{7.} & \multirow{3}{*}{$\begin{array}{l}\text { Management } \\
\text { orientation }\end{array}$} & Low (<51.83 score) & 29 & 24.17 \\
\hline & & Medium (51.83-60.73 & 42 & $35 / 00$ \\
\hline & & High (>60.73 score) & 49 & 40.83 \\
\hline \multirow[t]{3}{*}{8.} & \multirow{3}{*}{$\begin{array}{l}\text { Scientific } \\
\text { orientation }\end{array}$} & Low (<33.41 score) & 24 & 20.00 \\
\hline & & Medium (33.41-35.81 & 40 & 33.33 \\
\hline & & High (>35.81 score) & 56 & 46.67 \\
\hline \multirow[t]{3}{*}{9} & \multirow{3}{*}{$\begin{array}{l}\text { Mass media } \\
\text { participation }\end{array}$} & Low $(<12.94$ score $)$ & 33 & 27.50 \\
\hline & & Medium $\quad(12.94-16.38$ & 39 & 32.50 \\
\hline & & High (>16.38 score) & 48 & 40.00 \\
\hline \multirow[t]{3}{*}{10.} & \multirow{3}{*}{$\begin{array}{l}\text { Extension agency } \\
\text { contact }\end{array}$} & Low (<10.06 score) & 31 & 25.83 \\
\hline & & Medium $\quad(10.06-15.26$ & 37 & 30.83 \\
\hline & & High $(>15.26$ score $)$ & 52 & 43.34 \\
\hline
\end{tabular}


Table.2 Participation of farmers in the agricultural extension activities of Raitha Samparka Kendras

\begin{tabular}{|c|l|c|c|c|c|c|}
\hline \multirow{2}{*}{ SI. No. } & \multirow{2}{*}{ Extension activities* } & \multicolumn{5}{|c|}{ Farmers } \\
\cline { 4 - 6 } & & \multicolumn{2}{|c|}{ Participation } & Non participation \\
\cline { 4 - 6 } & & No. & $\%$ & No. & $\%$ \\
\hline $\mathbf{1}$ & Phone calls & 98 & 81.66 & 22 & 18.34 \\
\hline $\mathbf{a .}$ & Landline & 102 & 85.00 & 18 & 15.00 \\
\hline $\mathbf{b .}$ & Mobile & 88 & 73.33 & 32 & 46.67 \\
\hline $\mathbf{2}$ & Meetings/ Discussion & 63 & 52.50 & 57 & 47.50 \\
\hline $\mathbf{3}$ & Method demonstration & 61 & 50.83 & 59 & 49.17 \\
\hline $\mathbf{4}$ & Result demonstration & 71 & 59.16 & 49 & 40.84 \\
\hline $\mathbf{5}$ & Field visits & 82 & 68.33 & 38 & 31.67 \\
\hline $\mathbf{6}$ & Training programmes & 30 & 25.00 & 90 & 75.00 \\
\hline $\mathbf{7}$ & Farmers field school & 16 & 13.33 & 104 & 86.67 \\
\hline $\mathbf{8}$ & Video conference & 55 & 45.83 & 65 & 54.17 \\
\hline $\mathbf{9}$ & Field days /Kshethrotsava & 51 & 42.50 & 69 & 57.50 \\
\hline $\mathbf{1 0}$ & Agricultural campaign & 51 & 34.16 & 79 & 65.84 \\
\hline $\mathbf{1 1}$ & Agricultural exhibition & 42 & 18.33 & 98 & 81.67 \\
\hline $\mathbf{1 2}$ & Radio & 22 & 16.66 & 100 & 83.34 \\
\hline $\mathbf{1 3}$ & Television & 11 & 9.17 & 109 & 90.83 \\
\hline $\mathbf{1 4}$ & Internet & & & & \\
\hline & & & & & \\
\hline
\end{tabular}

*Multiple response

Table.3 Extent of participation of farmers in the agricultural extension activities of Raitha Samparka Kendras

\begin{tabular}{|c|c|c|c|}
\hline \multirow[t]{2}{*}{ Sl. No. } & \multirow[t]{2}{*}{ Participation category } & \multicolumn{2}{|c|}{ Farmers } \\
\hline & & No. & $\%$ \\
\hline 1 & Low (<6.22 score) & 38 & 31.66 \\
\hline 2 & Medium (6.22-8.38) & 42 & 35.01 \\
\hline 3 & High (>8.38 score) & 40 & 33.33 \\
\hline \multicolumn{2}{|r|}{ Total } & 120 & 100.00 \\
\hline \multicolumn{3}{|r|}{ Mean } & 8.30 \\
\hline \multicolumn{3}{|c|}{ Standard deviation } & 2.76 \\
\hline
\end{tabular}

$(n=120)$ 
Table.4 Relationship and extent of contribution of personal, socio-economic, psychological and communication characteristics of farmers on their participation in agricultural extension activities

\begin{tabular}{|c|l|c|c|c|c|}
\hline $\begin{array}{c}\text { Sl. } \\
\text { No. }\end{array}$ & \multicolumn{1}{|c|}{ Characteristics } & $\begin{array}{c}\text { Correlation } \\
\text { coefficient } \\
\text { value }\end{array}$ & $\begin{array}{c}\text { Regression } \\
\text { coefficient } \\
\text { (b) }\end{array}$ & $\begin{array}{c}\text { Standard Error } \\
\text { of Regression } \\
\text { coefficient }\end{array}$ & 't' value \\
\hline $\mathbf{1}$ & Age & $0.028^{\mathrm{NS}}$ & 0.194 & 0.1769 & $0.911^{\mathrm{NS}}$ \\
\hline $\mathbf{2}$ & Education & $0.248^{*}$ & 0.318 & 0.6719 & $2.111^{*}$ \\
\hline $\mathbf{3}$ & Land holding & $0.111^{\mathrm{NS}}$ & 0.190 & 0.310 & $1.61^{\mathrm{NS}}$ \\
\hline $\mathbf{4}$ & Annual income & $0.178^{\mathrm{NS}}$ & 0.112 & 0.179 & $1.59^{\mathrm{NS}}$ \\
\hline $\mathbf{5}$ & Farming experience & $0.0789^{\mathrm{NS}}$ & 0.894 & 0.9210 & $1.030^{\mathrm{NS}}$ \\
\hline $\mathbf{6}$ & Achievement motivation & $0.2968^{* *}$ & 0.124 & 0.519 & $4.180^{* *}$ \\
\hline $\mathbf{7}$ & Management orientation & $0.1968^{*}$ & 0.279 & 0.812 & $2.910^{*}$ \\
\hline $\mathbf{8}$ & Scientific orientation & $0.2130^{*}$ & 0.016 & 0.3178 & $2.728^{* *}$ \\
\hline $\mathbf{9}$ & Mass media participation & $0.2968^{* *}$ & 0.209 & 0.441 & $2.110^{*}$ \\
\hline $\mathbf{1 0}$ & Extension agency contact & $0.3611^{* *}$ & 0.220 & 0.612 & $2.780^{* *}$ \\
\hline
\end{tabular}

NS: Non-Significant; *Significant at $5 \%$ level; ** Significant at $1 \%$ level; $\mathrm{R}^{2}=0.644$

Overall participation of farmers in the agricultural extension activities of Raitha Samparka Kendras

It is observed from Table 3 that as high as 35.01 per cent of the farmers were belonging to medium level of participation in the agricultural extension activities, while 33.33 per cent of the farmers were belonging to high level and the remaining 31.66 per cent of the farmers were belonging to low level of participation in the agricultural extension activities of RSKs. It can be concluded that a majority of 68.34 per cent of the farmers were belonging to medium to high level of participation in the agricultural extension activities of RSKs. A large number of the farmers had participated in the extension activities such as, meetings/discussion, training programmes, field visits, method demonstration and result demonstration, besides contacting extension functionaries through mobile or landline phones, hence majority of the farmers $(68.34 \%)$ were belonging to medium to high level of participation in the agricultural extension activities of RSKs.
Relationship and extent of contribution of personal, socio-economic, psychological and communication characteristics of farmers on their participation in agricultural extension activities

Zero order correlation test was used to know the relationship between the profile characteristics of farmers and their extent of participation in agricultural extension activities. Whereas, multiple regression analysis was employed to find out the extent of contribution of profile characteristics on the participation of farmers in agricultural extension activities.

The results in Table 4 reveals that age, land holding, annual income and farming experience and farmers had no significant relationship with their participation in agricultural extension activities, while education, scientific orientation and mass media participation of farmers has significant relationship at five per cent level with their participation in agricultural extension activities. Variables such as, achievement motivation, management orientation and 
extension agency contact of farmers had highly significant relationship at one per cent level with their participation in agricultural extension activities. The findings are in line with the findings of Sathish et al., (2016) and Madan Mohan Reddy et al., (2017).

It is also observed from Table 4 that out of the ten of personal, socio-economic, psychological and communication characteristics studied, six variables namely, education, achievement motivation, management orientation, scientific orientation, mass media participation and extension agency contact of farmers were found significant in contribution to participation of in agricultural extension activities. All the ten independent variables contributed to the tune of 64.40 per cent revealed the significance at one per cent level of regression equation in predicting the results. The findings reveals that education, achievement motivation, management orientation, scientific orientation, mass media participation and extension agency contact of farmers have significantly contributed in increasing the participation in agricultural extension activities of Raitha Samparka Kendras.

Participation of farmers in the agricultural extension activities such as video conference, farmers field school, agricultural exhibition, agricultural campaign and field days/ kshethrotsava is low.

Hence, there is a need by the extension personnel to inform the farmers during their visit to farmers fields or through mass media about the venue and date of conduct of such agricultural extension activities for increasing the farmers' participation in familiarizing the

\section{How to cite this article:}

Darshan, M. E., M. T. Lakshminarayan and Banuprakash, K. G. 2019. Participation of Farmers in Agricultural Extension Activities of Raitha Samparka Kendras. Int.J.Curr.Microbiol.App.Sci. 8(09): 699-706. doi: https://doi.org/10.20546/ijcmas.2019.809.084 various activities of Raitha Samparka Kendras.

\section{References}

Avinash, T. S., 2013,Perception of farmers about functioning of Raitha Samparka Kendras in Dharwad district of Karnataka, M.Sc. (Agri.)Thesis (UNPUB.), Univ. Agric. Sci., Dharwad

Madan Mohan Reddy, K., Sreenivasa Rao, I., Srinivasulu, M., and Satish Kumar, G.D., 2017, Perception and Usefulness of Mobile Phone Based Agro-Advisories, Int. J. Curr. Microbiol. App. Sci,6 (7): 866872

Ramappa Patil, 2014, A study on performance of Raitha Samparka Kendras in Davanagere District of Karnataka, M.Sc. (Agri.) Thesis (Unpub.), Univ. Agric. Sci., Bangalore

Raghupathi, D., Venkatesha, M. and Vijayaraghavan., 2011, Opinion of clientele towards Raitha Samparka Kendras.Mysore J. Agric. Sci.,45 (1):124127

Raghuprasad, K. P., Akarsha, B. M. and Raghavendra, K., 2012, Raitha samparka kendras and their role in agro- information delivery, J. Agric. Sci., 25 (1): 82- 85

Sathish, H.S., Chandargi, D.M. and Meti. S.K., 2016, Farmers perception of service quality of extension services provided by public extension organizations, International Journal of Science, Environment and Technology, 5 (5):3575 $-3582$

Sunil Vasant More, 2014, Perception of the Beneficiaries about Farmers Field School Programme in Konkan Region of Maharasthra, M.Sc (Agri.) Thesis (UNPUB.), Dr Balasaheb Sawant Konkan Krishi Vidyapeeth., Dapoli 